\title{
Potential of Pre-harvest Application of Burkholderia spinosa for Biological Control of Epiphytic and Pathogenic Microorganisms on the Phyllosphere of Banana (Musa spp.)
}

\author{
Y.M.U.K. Yapa Silva* and D.M. De Costa ${ }^{1}$ \\ Postgraduate Institute of Agriculture \\ University of Peradeniya \\ Sri Lanka
}

\begin{abstract}
A study was conducted to determine the effects of pre-harvest application of a bacterial antagonist, Burkholderia spinosa on the population dynamics of epiphytic and pathogenic microorganisms dwelling on banana (Musa spp.) leaves together with the population build-up of the applied bacterial antagonist. Banana cultivar Kolikuttu was established as an outdoor plot experiment and the antagonist was applied by two methods (i.e. a foliar spray and a soil drench) at nine times (i.e. $300 \mathrm{ml}$ per plant per time) repeatedly at weekly intervals. Effects of leaf washings of plants treated with different application methods on germination of $\underline{C}$. musae, the causal organism of several postharvest diseases of banana, spores were investigated in vitro. There was a significant $(p<0.0001)$ interaction effect between time and method of $\underline{B}$. spinosa application on the density of the bacterial antagonist on banana leaves. A gradual build-up of $\underline{B}$. spinosa was observed on leaves with a peak density at 228 days after planting when bacterial antagonist was applied as a foliar spray. Burkholderia spinosa was not found on leaves of banana when the plants were treated as a soil drench or left untreated with the antagonist. Densities of Aspergilus spp. and unidentified fungal species on leaves of banana were significantly influenced by the method

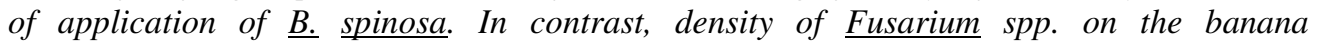
phyllosphere varied significantly with the time of application $(p<0.001)$. The density of yeast and unidentified bacterial species on banana leaves was not significantly influenced by the time and method of application or their interaction effect. Application of $\underline{B} \underline{\text { spinosa }}$ as a soil drench could reduce phyllosphere pathogens, Aspergillus spp. and Fusarium spp. Percentage germination of $\underline{C}$. musae spores continued to increase $24 \mathrm{~h}$ after incubation in the leaf washing of control banana plants. In contrast, leaf washings of $\underline{B}$. spinosa treated plants showed a decline in the percentage spore germination. The findings of the present study revealed the ability of $\underline{B}$. spinosa for building up considerable cell densities on the treated leaf surface and its ability for suppressing a range of microbes. These are desirable features of $\underline{B}$. spinosa to be used in field application for the control of foliar pathogens of banana.
\end{abstract}

Keywords: Antagonistic effect, banana, Burkholderia spinosa, foliar application, leaf washing, soil drench

\footnotetext{
1 Department of Agricultural Biology, Faculty of Agriculture, University of Peradeniya, Sri Lanka

* Corresponding author: ymujitha@yahoo.co.uk
} 


\section{INTRODUCTION}

Banana (Musa spp.) is an economically-significant fruit crop in many developing countries as a source of energy and nutrients and a valued source of income generation through local and international trade. Potential yield of banana is reduced by a number of pre- and postharvest diseases. Banana fruits grow and develop until harvest in an aerial environment which influences biological events such as disease initiation and development on the host plant (Alvindia et al., 2006). A wide range of fungi and bacteria, both pathogenic and beneficial have been detected on developing banana fruits (De Costa \& Subasinghe, 1998; Alvindia et al., 2006). Incidence of some of the postharvest diseases, namely anthracnose and crown rot caused by Colletotrichium musae has a significant positive relationship with the population density of the pathogen on flower parts at the pre harvest stage of the crop. Moreover, a positive correlation between the number of dead leaves per plant and the incidence of anthracnose was observed in Queensland (Simmonds \& Mitchell, 1940) suggesting that trashed leaves could increase the quantity of primary inoculums. Conidia on plant parts can act as inoculum sources through rain splashing over 2-3 $\mathrm{m}$ distance (Waller, 1972). Hence, reducing the inoculum density at preharvest stage is a strategy to reduce disease incidences at the postharvest stage.

In addition to the harbouring of primary inoculum of several postharvest diseases, leaves of banana are affected by foliage diseases such as black sigatoka, yellow sigatoka, cordana and several other leaf spot diseases caused by fungal pathogens Mycosphaerella fijiensis, Mycosphaerella musicola, Cordana musae, Cercospora and Phyllosticta respectively. Anthracnose and crown rot of banana were primarily controlled by postharvest application of thiabendazole (Rippon \& Glennies-Holmes, 1973). However, the treatment has been recently hampered by the emergence of strains resistant to this fungicide (Johanson \& Blasquez, 1992). Sterol inhibitor fungicides of the DMI (demethylation inhibitor) group were reported to be very effective but the authorized fungicide residue levels in the fruits for these compounds are very low, thus limiting their use (de Lapeyre de Bellaire and Nolin, 1994). Considering the environmental and health hazards associated with the application of fungicides, there is a strong public and scientific desire to seek for and eco-friendly alternatives for the management of such diseases (Mari et al., 2007).

To this end, microbial antagonists which occur naturally on plant surfaces can be promoted and managed or microbial antagonists can be artificially introduced (Sharma et al., 2009). Several modes of action have been suggested to explain the biocontrol activity of these microbial antagonists, namely competition for nutrients and space between pathogen and the antagonist, direct parasitism, antibiosis and induced resistance of the host plant (Sharma et al., 2009). Thangavelu \& Mustaffa (2012) have highlighted the efficiency of controlling Fusarium wilt of banana, by application of microbial antagonists namely, Trichoderma spp., Pseudomonas spp., Bacillus spp. as soil treatments, due to synthesis of defense-related enzymes as a result of host plant resistance induced by exogenous application of the microbial antagonists. Therefore, biological control by antagonistic microbes can be used as a potential strategy of reducing the density of pathogen population and a measure of inducing host plant resistance.

Burkholderia spinosa, a bacterium isolated from the peel tissues of banana has been proved for its antagonism against $C$. musae, under in vitro conditions and ability to reduce the rate of anthracnose development on different banana varieties when applied as a postharvest dip treatment (De Costa \& Erabadupitiya, 2005: De Costa et al., 2008) 
The present study was conducted to determine the population dynamics of epiphytic and pathogenic microbes inhabiting on the phyllosphere when the banana plants were treated with $B$. spinosa as a preharvest foliar spray and a soil drench. Moreover, it assessed the retention/colonising efficiency of $B$. spinosa on leaf tissues of banana when the plants were treated by the two methods. Effects of field application of the biocontrol agent on survival and germination of $C$. musae spores were also investigated.

\section{MATERIALS AND METHODS}

\section{Crop establishment}

A plot experiment was conducted at the experimental field of Faculty of Agriculture, University of Peradeniya, during the period from July 2012 to June 2013. Average minimum and maximum day temperature, mean rainfall per day and mean sunshine hours during the experiment period were $20.9^{\circ} \mathrm{C}, 29.4^{\circ} \mathrm{C}, 9.1 \mathrm{~mm}$ per day and $6.3 \mathrm{~h}$ respectively. Banana plants (cultivar Kolikuttu) were purchased from Tissue culture laboratory, Mahaweli Authority of Sri Lanka, Embilipitiya, planted and maintained according to recommendations of Department of Agriculture. Each plant was covered with a polythene guard by inserting a $15 \mathrm{~cm}$ section below the ground level. This was done to prevent the attack from wild animals and to prevent the lateral mixing of different treatments.

\section{Microbial cultures}

Collectotrichium musae was isolated from banana fruit (cultivar Kolikuttu) showing typical anthracnose symptoms and pure cultures were maintained on PDA medium supplemented with the Streptomycin sulphate $(10 \mu \mathrm{g} / \mathrm{ml})$._B. spinosa was retrieved from stock cultures in sterile distilled water and maintained at the Laboratory of Plant Pathology and Microbiology, Department of Agricultural Biology, Faculty of Agriculture, and confirmed the purity and antagonism. Antagonism was confirmed by dual culture plate method (De Costa et al., 2008). B. spinosa cell suspensions were prepared in nutrient broth to have a final cell concentration of $10^{8} \mathrm{CFU} / \mathrm{ml}$.

\section{Application of treatments}

Cell suspensions of $B$. spinosa at a concentration of $10^{8} \mathrm{CFU} / \mathrm{ml}$ were applied to banana plants as a Foliage Spray (FS) and a Soil Drench (SD). Foliage spray (300 ml per plant) was applied to both sides of the leaves using a hand sprayer until the leaves were thoroughly wet. A volume of $300 \mathrm{ml}$ of the cell suspension was added to the base of the plants as a Soil Drench per plant at a time. Water was used for the control treatment in both application types. Applications were repeated at weekly intervals, from 130 days after planting till 208 days after planting (i.e. 9 times). Each treatment was replicated three times and the treatments were arranged in the field according to a completely randomized design.

\section{Quantifications of epiphytic microorganisms}

Leaf samples were collected one week after treatment with $B$. spinosa either as a FS or a SD (i.e. 137 days after planting) and continued 9 times at weekly intervals (i.e. until 215 days after planting). Ten leaf discs having a $2 \mathrm{~cm}$ diameter were cut from randomly selected areas of fully grown leaves from each plant. At a time, ten discs were taken per plant. Leaf discs from each plant were vortexed with $1 \mathrm{ml}$ sterile distilled water and plated on PDA medium 
and Nutrient agar (NA) medium separately by serial dilution plate technique. Fungal including yeasts and bacterial colonies which were appeared on PDA and NA media respectively were quantified as colony forming units per $\mathrm{ml}$ till five days after incubation at $28 \pm 2{ }^{\circ} \mathrm{C}$. Quantification was repeated twice with three replicates per treatment at each experiment.

\section{Quantification of C. musae on banana leaves}

Spore suspension of $C$. musae having a concentration of $10^{8}$ spores per $\mathrm{ml}$ was sprayed on to the leaves of banana using a hand held sprayer. The spraying of $C$. musae spores was done two days after application of $B$. spinosa either as a FS or a SD. Only a spore suspension $C$. musae was applied to the leaves of banana plants maintained as control treatments. Ten leaf discs, each having a $2 \mathrm{~cm}$ diameter were collected two days after the spraying of $C$. musae from banana leaves sprayed with $C$. musae. Leaf discs were separately vortexed in sterile distilled water. C. musae remaining on the leaf surface was quantified as colony forming units per ml by plating the vortexed sample on PDA and NA plates according to dilution plate technique. Quantification was repeated twice with three replicates per treatment at each experiment.

\section{Effects of leaf washing on germination of $C$. musae}

Similar area of banana leaves taken from the three treatments (i.e. FS, SD and control) was washed separately with sterile distilled water. The washings were filter sterilized using disposable syringe filters (having a pore diameter of $0.2 \mu \mathrm{m}$ ). Similar aliquots taken from the filter sterilized washing were placed in sterile glass Petri dishes. An aliquot of $0.5 \mathrm{ml}$ of $C$. musae spore suspension $\left(10^{3}\right.$ spores $\left./ \mathrm{ml}\right)$ was added to the sterilized washing and incubated at room temperature. Percentage spore germination was quantified at $18 \mathrm{~h}, 24 \mathrm{~h}, 48 \mathrm{~h}$ and $72 \mathrm{~h}$ after incubation. All the Petri dishes were introduced with $1 \mathrm{ml}$ of $4 \%$ filter sterilized glucose solution, as germinated spores were not found in the absence of a nutrient source.

\section{Data collection and analysis}

When quantification of the microbial colonies, number of deep yellow colonies appearing on NA medium was quantified as B. spinosa colonies as they produce characteristic circular shiny deep yellow coloured colonies on NA. The identity of these colonies was confirmed by Gram staining, $3 \% \mathrm{KOH}$ test and antagonism against $C$. musae by dual culture plate method (De Costa et al., 2008). Total bacterial, fungal and yeast colonies appearing on PDA plates were separately recorded based on colony and spore morphology. Density of each microorganism dwelling on banana leaves was calculated as cfu/ml. Significance of the variation of colony densities with different methods of application was tested using analysis of variance and means were separated using Duncan's New Multiple Range Test.

\section{RESULTS AND DISCUSSION}

\section{Population dynamics of $B$. spinosa on banana leaves}

B. spinosa density on banana leaves of the plants treated with different treatment methods over the experimental period is given by Table 1. Density of the bacterial antagonist varied significantly by the method of treatment, time of application of the treatment and the interaction effect of the method of treatment $\mathrm{x}$ time of application of the treatment 
( $\mathrm{p}<0.0001)$. Viable cells of $B$. spinosa were not present on banana leaves of the plants which were treated with the SD and the plants which were not treated with $B$. spinosa by any application method (control) (Table1). A gradual increase of $B$. spinosa was observed till 228 days after planting (DAP) and the highest density was reported at 228 DAP and a reduction thereafter. At 242 DAP, the colony density was significantly lower than that of 228 DAP but higher to the density reported during period from 130 - 214 DAP. B. spinosa colony density on phyllosphere from 130 DAP to 214 DAP had no significant difference among each other.

Table 1. Fluctuation of colony density of $B$. spinosa on banana leaves treated with three different treatments

\begin{tabular}{cccc}
\hline DAP & $\begin{array}{c}\text { B. spinosa-foliar } \\
\text { spray }(\mathrm{cfu} / \mathrm{ml}) \mathrm{x}\end{array}$ & $\begin{array}{c}\text { B. spinosa- soil } \\
\text { drench }(\mathrm{cfu} / \mathrm{ml}) \mathrm{x}\end{array}$ & $\begin{array}{c}\text { Control - (cfu/ml) x } \\
10^{3}\end{array}$ \\
\hline 130 & $2.94^{\mathrm{c}}$ & $10^{3}$ & 0.0 \\
144 & $2.42^{\mathrm{c}}$ & 0.0 & 0.0 \\
158 & $2.82^{\mathrm{c}}$ & 0.0 & 0.0 \\
172 & $4.18^{\mathrm{c}}$ & 0.0 & 0.0 \\
186 & $2.92^{\mathrm{c}}$ & 0.0 & 0.0 \\
200 & $8.60^{\mathrm{bc}}$ & 0.0 & 0.0 \\
214 & $25.00^{\mathrm{bc}}$ & 0.0 & 0.0 \\
228 & $66.00^{\mathrm{a}}$ & 0.0 & 0.0 \\
242 & $34.00^{\mathrm{b}}$ & 0.0 & 0.0 \\
\hline
\end{tabular}

Note: Means values having the same letter along a column are not significantly different at $\mathrm{p}=0.05$.

\section{Population dynamics of other naturally-dwelling fungi on banana leaves}

Colony density of Aspergillus spp. varied significantly among plants treated with different treatments $(\mathrm{p}<0.0059)$. A significantly higher colony density of Aspergillus spp. was recorded on the leaves of the control treatment in comparison to the other two treatments (i.e. BS-FS and BS-SD) (Fig. 1). In contrast to colony density of B. spinosa on banana leaves of control plants, Aspergillus spp. showed the highest colony density at 130 DAP and then a gradual reduction throughout the experimental period with the exception at 186 and 242 DAP. The lowest colony density throughout the experimental period with the exception at 186 DAP, was reported on the plants treated with B. spinosa as a foliar spray. Fig. 1 indicates the ability of $B$. spinosa in reducing the phyllospere inhabiting Aspergillus spp. when applied either as a foliar spray or a soil drench. Despite the absence of B. spinosa colonies on leaves of the plants treated with a soil drench (Fig. 1), reduction of the colony density of Aspergillus spp. could be due to a possible influence by induced host plant resistance caused by the microbial antagonist. Similar findings have been highlighted by Thangavelu \& Mustaffa (2012) and Kumar et al. (2011) in controlling foliar and systemic diseases when plant growth promoting rhizobacteria are applied as a soil treatment. 


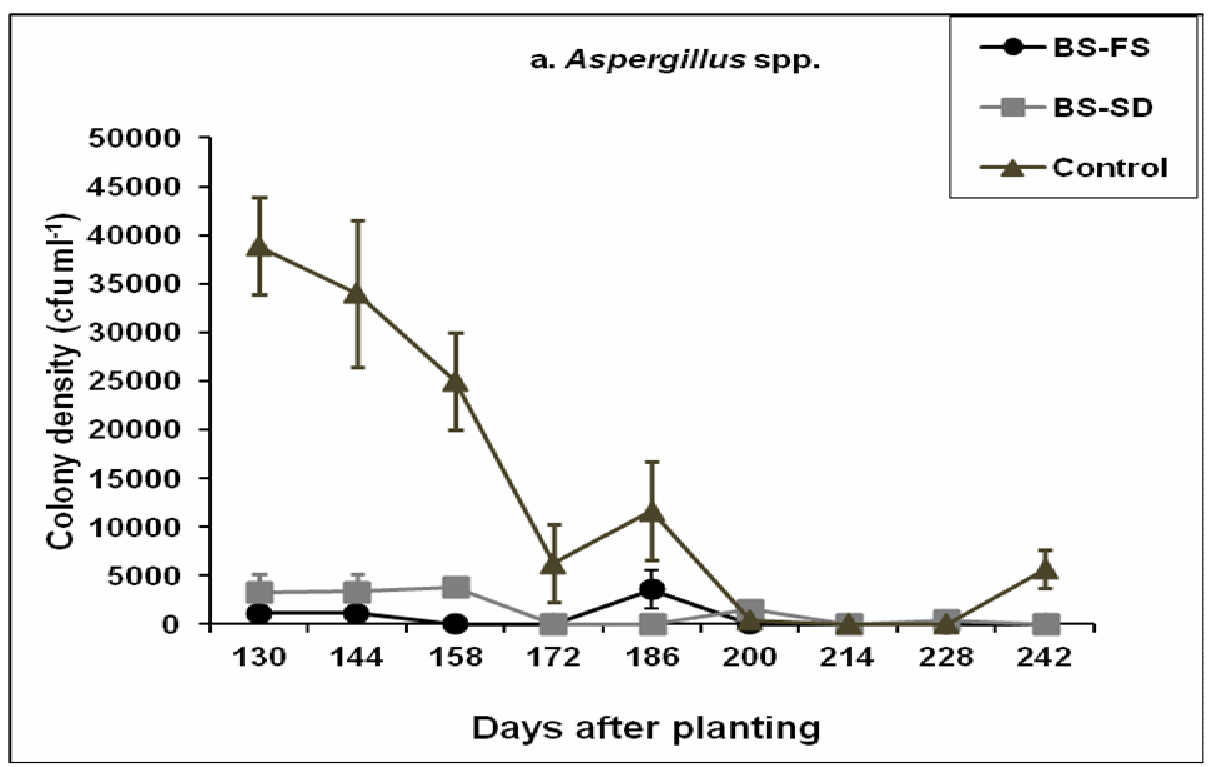

Fig. 1. Fluctuation of colony density of Aspergillus spp. on banana leaves treated with three different treatments with time (BS-FS: B. spinosa as a foliar spray, BSSD: $B$. spinosa as a soil drench, control: no application of $B$. spinosa either as a foliar spray or a soil drench)

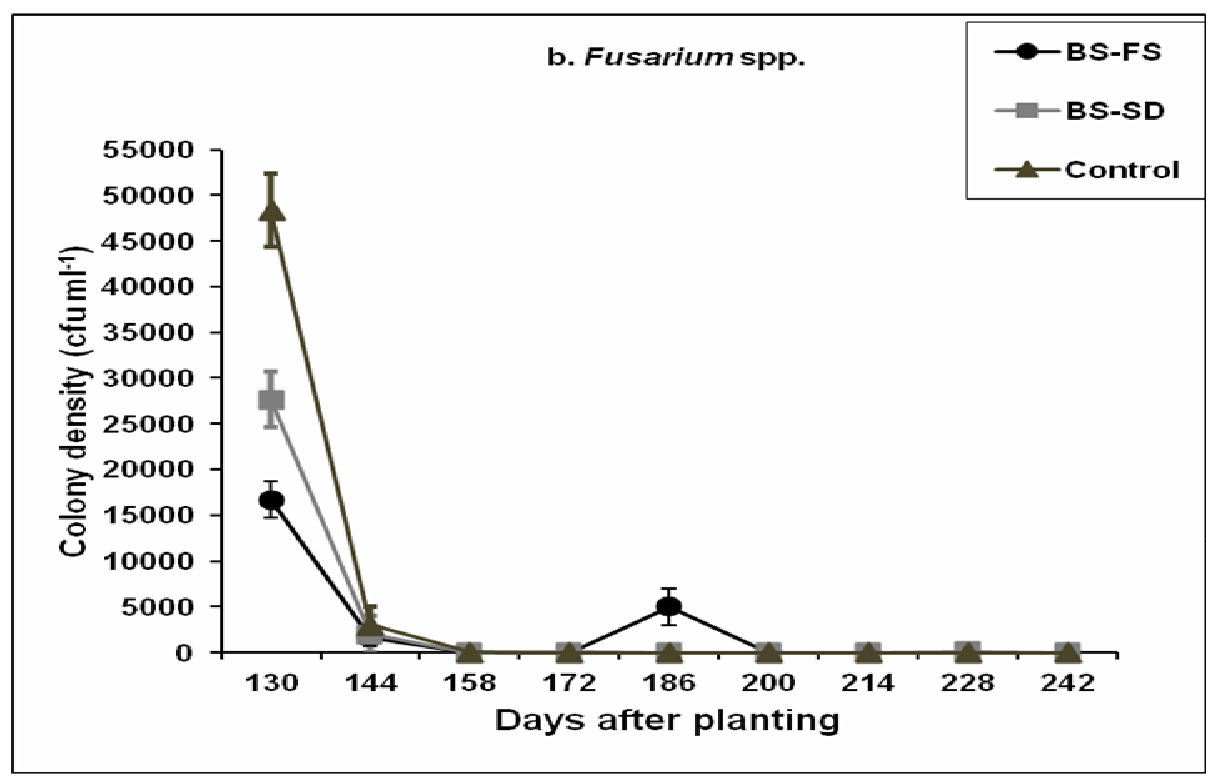

Fig. 2. Fluctuation of colony density of Fusarium spp. on banana leaves treated with three different treatments (BS-FS: $B$. spinosa as a foliar spray, BS-SD: $B$. spinosa as a soil drench, control: no application of $B$. spinosa either as a foliar spray or a soil drench) 
Colony density of Fusarium spp. was significantly varied with time of application $(\mathrm{p}<0.0001)$. At the initial stage of treatment of the plants (i.e. 130 DAP) colony density of Fusarium spp. was highest on leaves of control plants. The density of colonies varied significantly at 130 DAP, however the density showed no difference among each other at the rest of the time intervals (from 144 to 242 DAP). In general, density of Fusarium spp. dwelling on banana leaves was higher in comparison to epiphytic Aspergillus spp. on banana leaves. Plants treated with $B$. spionsa either as a FS or a SD showed a rapid decline to zero level, from the second application of the bacterial antagonist, indicating an antagonistic effect on survival of Fusarium spp. (Fig. 2). However, reasons for rapid decline reported for Fusarium spp. on leaves of control-treated plant from 144 DAP onwards are not clear.

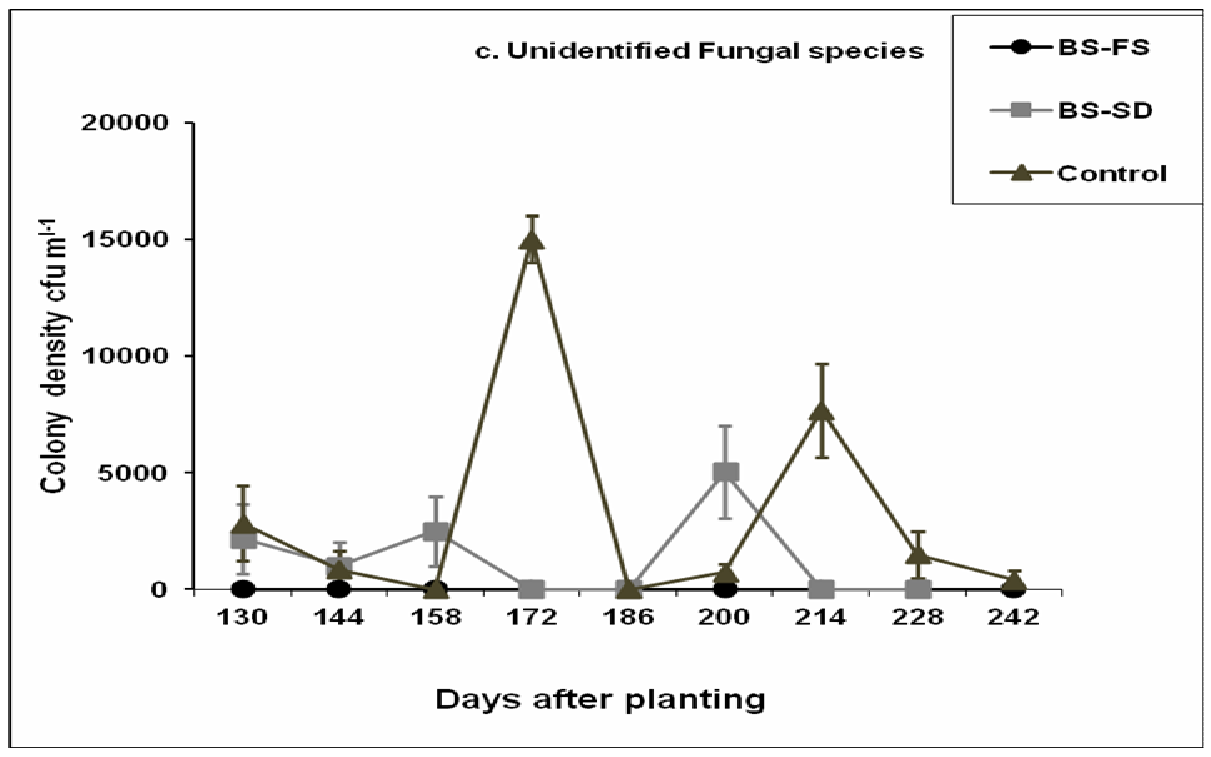

Fig. 3. Fluctuation of colony density of unidentified fungi on banana leaves treated with three different treatments with time of application (BS-FS: B. spinosa as a foliar spray, BS-SD: $B$. spinosa as a soil drench, control: no application of $B$. spinosa either as a foliar spray or a soil drench)

Density of unidentified fungal species differed among the three treatment methods significantly $(\mathrm{p}<0.0409) \quad$ (Fig. 3). Plants maintained as control treatment reported significantly higher density of fungi in comparison to plants treated with $B$. spinosa as a FS. Plants treated with $B$. spinosa as a FS did not allow the development of fungi classified as 'unidentified fungi' on leaves of banana. Leaves of control-treated plants and the plants treated with $B$. spinosa as a SD showed several peaks of fungal densities approximately in bi weekly intervals.

\section{Population dynamics of yeast and unidentified bacterial species on banana leaves}

Figure 4 presents the fluctuation of colony density of yeast and unidentified bacteria (b) on banana leaves treated with three different treatments. 


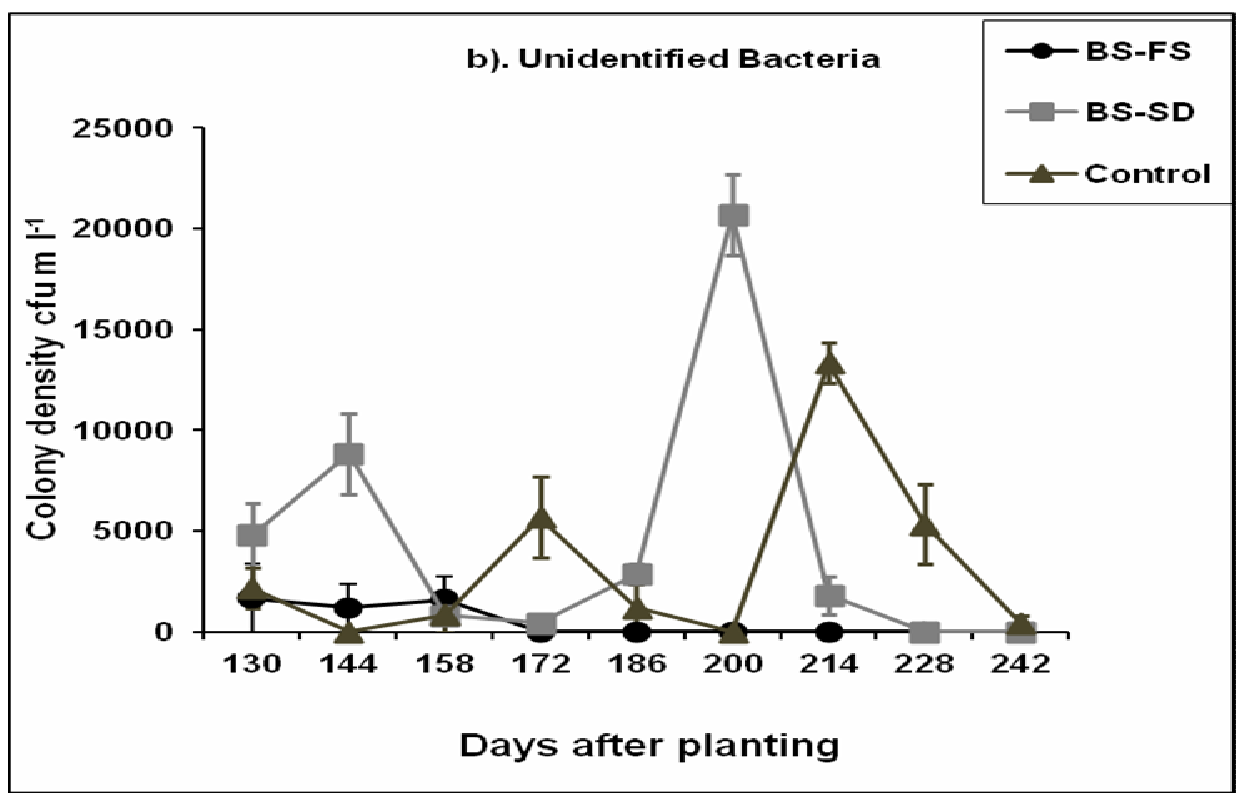

Fig. 4. Fluctuation of colony density of yeast (a) and unidentified bacteria (b) on banana leaves treated with three different treatments (BS-FS: $B$. spinosa as a foliar spray, BS-SD: $B$. spinosa as a soil drench, control: no application of $B$. spinosa either as a foliar spray or a soil drench)

Method of treatment, time after treatment or their interaction effect did not influence significantly on the colony densities of yeast and unidentified bacteria (other than $B$. spinosa) present on banana leaves $(\mathrm{p}=0.05)$. At the initial period of treatment, higher yeast density was reported by the plants treated as control. By 144 DAP the yeast density on control plants showed a reduction. In contrast, plants treated with $B$. spinosa as a foliar spray did not report yeast species throughout the experimental period, indicating an unfavourable microenvironmental condition for the growth of yeast due to the presence of B. spinosa on leaf surface. However, colony density of unidentified bacteria became zero from the 172 DAP and till then a higher colony density than that of control plants were reported from plants treated with $B$. spinosa as a FS. Leaves treated with $B$. spinosa as a soil drench reported a slightly higher colony density of yeast and unidentified bacteria than the plants treated with B. spinosa as a foliar spray with peak densities at 172 and 200 DAP. Higher colony density of unidentified bacterial species could be the endophytes or epiphytes present at times on plant leaves which had no detrimental effects by the microbial antagonist when applied as a soil drench. If these yeast and bacterial species are inhibitory to pathogens dwell on the leaves of the plant, they will provide an additional advantage on disease management.

\section{Quantification of $C$. musae on banana leaves}

C. musae colonies were not produced on PDA medium from the vortexed sample obtained from banana leaves which were artificially inoculated with a spore suspension of C. musae. This indicates the absence of viable spores on inoculated-leaves even after two days of inoculation. This could be due to the harmful effects of radiation and desiccation on spores. Environmental factors such as moisture, temperature and radiation have a large influence on the survival of fungal spores (Caesar \& Pearson, 1983; Stevenson \& Pennypacker, 1988). 
Although short wavelength UV radiation $(250-270 \mathrm{~nm})$ is a very small component of solar radiation, it is the main fungicidal element of solar radiation (Boyd-Wilson et al., 1998).

\section{Effects of leaf washing on germination of $C$. musae}

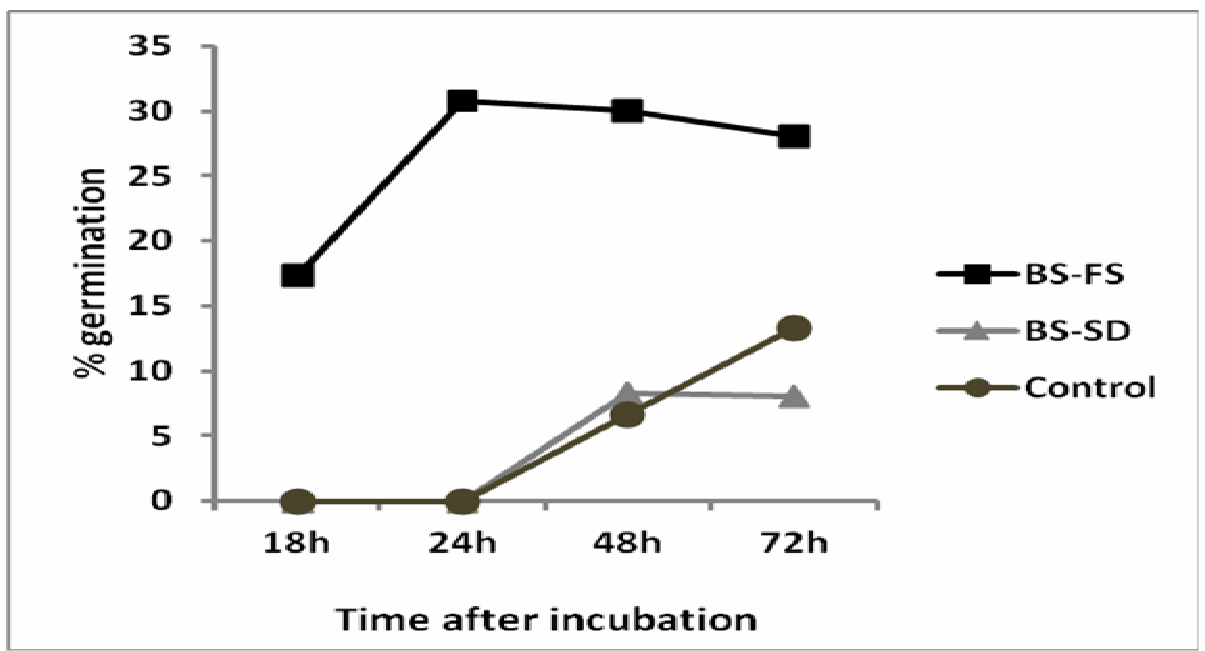

Fig. 5. Percentage germination of spores of $C$. musae on leaf washings obtained from banana treated with three treatments (BS-FS: $B$. spinosa as a foliar spray, BSSD: $B$. spinosa as a soil drench, control: no application of $B$. spinosa either as a foliar spray or a soil drench)

Percentage germination of conidia continued to increase $24 \mathrm{~h}$ after incubation in the leaf washings obtained from control banana leaves. However, the leaf washings of the other two treatments showed a decline of spore germination. The higher percentage spore germination observed in leaf washings obtained from foliar sprayed-leaves could be due to the nutrients of the culture medium remained on the leaves when the microbial antagonist was sprayed as a foliar spray.

The microbial communities of leaves are diverse and include many different genera of bacteria, actinomycetes, filamentous fungi, yeast and less frequently protozoa and nematodes (Brighna et al., 1997). Findings of the present study agree with the rich diverse nature of microbial community on the phyllosphere of banana having a range of fungal, yeast and bacteria. Aspergillus spp. such as A. nidulans, A. flavus and Fusarium spp. such as $F$. semitectum, F. moniliforme have been reported as pathogens of banana (Rodage \& Suryawanshi, 2013; Jones \& Stover, 2000; Murihead \& Jones, 2000). Raaijmakers et al. (1995) reported that effective colonization and high population size of the introduced bacterial biological control agents on plant surfaces have been considered to be an important factor in the successful control of plant diseases. Results of the present study are also in agreement with Raaijmakers et al. (1995) showing the potential of effective colonization and high population size of the introduced biological control agent, $B$. spinosa on phyllosphere. Ji \& Wilson (2003) also studied the enhancement of population size of a biological control agent and their bio-efficacy in the control of bacterial speck of tomato through salicylate and ammonium surface amendments. Use of phyllosphere inhabiting actinomycete for the control 
of foliar pathogen of cucumber (Corynespora cassiicola) has been reported (Wang \& Ma, 2011).

When considered the population build-up on banana leaves and the ability to suppress other microbial colonies on banana leaves, use of B. spinosa as a foliar spray can be considered as an effective method to control pathogenic microbial populations growing on the phyllosphere. The potential ability of $B$. spinosa to be used as a field spray was further supported by the simulation in vitro study of spore germination of $C$. musase in different types of leaf washings.

\section{CONCLUSIONS}

Application of $B$. spinosa as a foliar spray in weekly intervals for nine repetitive times suppresses the abundance of Aspergillus spp., Fusarium spp. and several other unidentified bacteria, fungi and yeast spp. dwell on banana leaves. B. spinosa when applied as a soil drench could reduce phyllosphere pathogens, Aspergillus spp. and Fusarium spp. Foliar spraying of $B$. spinosa built up the colony density on banana leaves at a concentration of $10^{5}$ $\mathrm{cfu} / \mathrm{ml}$ by the end of $228 \mathrm{DAP}$.

\section{REFERENCES}

Alvindia, D.G., Kobayashi, T. and Natsuaki, K.T. (2006). The aerial and fruit surface populations of fungi in nonchemical banana production in the Philippines. J. Gen. Plant Pathol. 72, 257 - 260.

Brighna, L.M., Ravenelli, A., Monelli, A. and Ercoli, R. (1997). The use of epiphyte as bioindicator of air pollution in Costa Rica. Science and Environment, 198, 175 - 180.

Boyd-Wilson, K.S.H., Perry, J.H. and Walter, M. (1998). Persistence and survival of saprophytic fungi antagonistic to Botrytis cinerea on kiwifruit leaves. Proceedings of the $51^{\text {st }}$ New Zealand Plant Protection Conference, 51, 96 - 101.

Caesar, A.J. and Pearson, R.C. (1983). Environmental factors affecting survival of ascospores of Sclerotinia sclerotiorum. Phytopath. 73, 1024 - 1030.

De Costa, D. M. and Subasinghe, S.S.N.S. (1998). Antagonistic bacteria associated with the fruit skin of banana in controlling its postharvest diseases, Tropical Science. 38, 206 - 212.

De Costa, D.M., Erabadupitiya, H.R.U.T. (2005). An integrated method to control postharvest diseases of banana using a member of the Burkholderia cepacia complex. Postharvest Biol Tech. 36, 31 - 39.

De Costa, D.M., Zahra, A.R.F., Kalpage, M.D. and Rajapakshe, E.M.G. (2008). Effectiveness and molecular characterization of Burkholderia spinosa, a prospective biocontrol agent for controlling postharvest diseases of banana. Biol. Control, 47, 257 - 267.

De Lapeyer de Bellaire, L. and Nolin, J. (1994). Amélioration du contrôle du chancre sur les bananes d'exportation et traitements post-récolte. Fruits. 49, 179 - 185. 
Ji, P. and Wilson, M. (2003). Enhancement of population size of a biological control agent and efficacy in control of bacterial speck of tomato through salicylate and ammonium sulfate amendments, App. Environ. Microbiol. 69(2), 1290 - 1294.

Johanson, A. and Blasquez, B. (1992). Fungi associated with banana crown-rot on fieldpacked fruit from the Wind-ward islands and assessment of their sensitivity to the fungicides thiabendazole, prochloraz and imazalil. Crop Prot. 11, 79 - 83.

Jones D.R. and Stover, R.H. (2000). Fungal diseases of banana fruit, preharvest diseases. In: Jones, D.R. (Ed.), pp. 173-190. Diseases of Banana, Abacá and Enset. CABI Publishing, Wallingford, UK.

Kumar, A., Prakash, A. and Johri, B.N. (2011). Bacillus as PGPR in crop ecosystem. Pp 3759. In: Maheshwari, D.K. (Ed.). Bacteria in Agrobiology: Crop Ecosystems. SpringerVerlag, Berlin, Heidelberg.

Mari, M., Torres, R., Casalini, L., Lamarca, N., Mandrin, J.F., Lichou, J., Larena, I., de Cal, M.A., Melgarejo, P. and Usall, J. (2007). Control of postharvest brown rot on nectarine by Epicoccum nigrum and physic-chemical treatments. J. Sci. Food Agriculture. 87(7), 1271 1277.

Muirhead, I.F. and Jones, D.R. (2000). Fungal diseases of banana fruit, postharvest diseases. In: Jones, D.R. (Ed.). Diseases of Banana, Abacá and Enset, pp. 190-206. Wallingford, UK: CABI Publishing.

Raaijmakers, J. M., Leeman, M., van Oorschot, M. M. P., van der Sluis, I., Schippers, B. and Bakker, P. A. H. M. (1995). Dose-response relationship in biological control of Fusarium wilt of radish by Pseudomonas spp. Phytopathol. 85, 1075 - 1081.

Rippon, L.E. and Glennies-Holmes, L. (1973). Post-harvest dipping of bananas. Agricultural Gazette of New South Wales. 84, 229 - 231.

Rodage, T.S. and Suryawanshi, N.S. (2013). Isolation of fungal pathogens from infected banana fruits and its control using Trichoderma, Bionano Frontier, 6(2), 1 - 2.

Simmonds, J.H. and Mitchell, R.S. (1940). Black end and anthracnose of the banana with special reference to Gleosporium musarum and Colletotrichum. Bulletin of Country Science and Industrial Research of Australia. No. 131.

Sharma, R.R., Singh, D. and Singh, R. (2009). Biological control of postharvest diseases of fruits and vegetables by microbial antagonists: A review. Biol. Control. 50, 205-221.

Stevenson, R.E. and Pennypacker, S.P. (1988). Effect of radiation, temperature and moisture on conidial germination of Alternaria solani. Phytopathol. 78, 926 - 930.

Thangavelu, R. and Mustaffa, M.M. (2012). Current advances in Fusarium wilt disease management in banana with emphasis on biological control. In: Cumagun, C.J. (Ed.) Plant Pathology, InTech, Available from: http://www.intechopen.com/books/plantpathology/current-advancesin- the-fusarium-wilt-disease-management-in-banana-withemphasis-on-biological-contr 
Waller, J.M. (1972). Water-borne dispersal in coffee berry disease and its relation to control. Ann. Appl. Biol. 71, 1 - 18.

Wang, M. and Ma, Q. (2011). Antagonistic actinomycete XN-1 from phyllosphere microorganisms of cucumber to control Corynespora cassiicola, Cucurbit Genetics Cooperative Report, 33-34, 17-21. 